\title{
Do host genetic traits in the bacterial sensing system play a role in the development of Chlamydia trachomatis-associated tubal pathology in subfertile women?
}

\author{
Janneke E den Hartog*1, Sander Ouburg2, Jolande A Land ${ }^{1,6}$, \\ Joseph M Lyons ${ }^{3,6}$, James I Ito ${ }^{3,6}$, A Salvador Peña ${ }^{2,6}$ and \\ Servaas A Morré2,4,5,6
}

Address: ${ }^{1}$ Research Institute Growth and Development (GROW) and Department of Obstetrics and Gynaecology, Academic Hospital Maastricht, P.O. Box 5800, 6202 AZ Maastricht, The Netherlands, ${ }^{2}$ Laboratory of Immunogenetics, Section Immunogenetics of Infectious Diseases, Department of Pathology, VU University Medical Center, Van der Boechorststraat 7, 1081 BT Amsterdam, The Netherlands, ${ }^{3}$ Department of Infectious Diseases, City of Hope National Medical Center and Beckman Research Institute, 1500 E. Duarte Road, Duarte, California 91010, USA, ${ }^{4}$ Department of Internal Medicine, Section Infectious Diseases, VU University Medical Center, Van der Boechorststraat 7, 1081 BT Amsterdam, The Netherlands, ${ }^{5}$ Department of Medical Microbiology, Academic Hospital Maastricht, P.O. Box 5800, 6202 AZ Maastricht, The Netherlands and ${ }^{6}$ On behalf of the ICTI consortium (Integrated approach to the study of Chlamydia trachomatis Infections) and the EpiGenChlamydia consortium

Email: Janneke E den Hartog* - je_denhartog@hotmail.com; Sander Ouburg - s.ouburg@vumc.nl; Jolande A Land - jlan@sgyn.azm.nl; Joseph M Lyons - jlyons@coh.org; James I Ito - jito@coh.org; A Salvador Peña - as.pena@vumc.nl;

Servaas A Morré - samorretravel@yahoo.co.uk

* Corresponding author

Published: 21 July 2006

BMC Infectious Diseases 2006, 6:122 doi:10.1 186/147/-2334-6-122

This article is available from: http://www.biomedcentral.com/I47I-2334/6/I22

(c) 2006 den Hartog et al; licensee BioMed Central Ltd.

This is an Open Access article distributed under the terms of the Creative Commons Attribution License (http://creativecommons.org/licenses/by/2.0), which permits unrestricted use, distribution, and reproduction in any medium, provided the original work is properly cited.

\begin{abstract}
Background: In women, Chlamydia (C.) trachomatis upper genital tract infection can cause distal tubal damage and occlusion, increasing the risk of tubal factor subfertility and ectopic pregnancy. Variations, like single nucleotide polymorphisms (SNPs), in immunologically important host genes are assumed to play a role in the course and outcome of a C. trachomatis infection. We studied whether genetic traits (carrying multiple SNPs in different genes) in the bacterial sensing system are associated with an aberrant immune response and subsequently with tubal pathology following a $C$. trachomatis infection. The genes studied all encode for pattern recognition receptors (PRRs) involved in sensing bacterial components.
\end{abstract}

Methods: Of 227 subfertile women, serum was available for $C$. trachomatis $\lg$ antibody testing and genotyping (common versus rare allele) of the PRR genes TLR9, TLR4, CDI4 and CARDI5/NOD2. In all women, a laparoscopy was performed to assess the grade of tubal pathology. Tubal pathology was defined as extensive peri-adnexal adhesions and/or distal occlusion of at least one tube.

Results: Following a C. trachomatis infection (i.e. C. trachomatis IgG positive), subfertile women carrying two or more SNPs in C. trachomatis PRR genes were at increased risk of tubal pathology compared to women carrying less than two SNPs ( $73 \%$ vs $33 \%$ risk). The differences were not statistically significant ( $P$ $=0.15)$, but a trend was observed.

Conclusion: Carrying multiple SNPs in C. trachomatis PRR genes tends to result in an aberrant immune response and a higher risk of tubal pathology following a $C$. trachomatis infection. Larger studies are needed to confirm our preliminary findings. 


\section{Background}

A large variation exists in the individual response to a Chlamydia (C.) trachomatis infection. Some women clear a C. trachomatis infection adequately without developing tissue damage, whereas others get a persistent infection which may ascend to the upper genital tract, increasing the risk of tubal damage and subfertility. The susceptibility, course and outcome of infectious diseases are determined by environmental factors, virulence factors of the pathogen and host factors.

Immunogenetic studies evaluate the role of genetic variations in immunologically important host genes as determinants of the susceptibility, course and outcome of infectious diseases. Among these variations are single nucleotide polymorphisms (SNPs), in which one nucleotide has been substituted, inserted or deleted. This may lead to synthesis of a potentially aberrant protein, or to up- or downregulation of the normal protein, and subsequently to an aberrant immune response, increasing the risk of late sequelae of infectious diseases (e.g. tubal pathology following a C. trachomatis infection).

In the present study, we have evaluated SNPs in genes encoding for pattern recognition receptors (PRRs). PRRs are present on or in circulating cells of the innate immune system (e.g. macrophages) and local cells (e.g. epithelial cells of the upper genital tract). PRRs are involved in the bacterial sensing pathways of the innate immune system by recognizing the so-called pathogen-associated molecular patterns (PAMPs), which are pathogen-specific cell wall components or intracellular components. Since different PRRs recognize different PAMPs, pathogen recognition and initiation of the immune response is a complex and flexible system.

Carrying a SNP in a single PRR may not result in a large effect on disease severity, since other PRRs may compensate for the partial loss of function in a specific pathogen recognition route. Subsequently, SNPs in only one PRR may not play a significant role as risk factors for the development of C. trachomatis-associated tubal pathology, as shown for the PRR toll-like receptor (TLR) 4 [1] and its co- receptor cluster of differentiation (CD) 14 [2]. However, carrying multiple SNPs in one gene or in multiple genes (in so-called carrier traits) may be associated with an increased risk of tubal pathology. Smirnova et al. (2003) [3] have found that combinations of TLR4 variants are markedly more common in patients with meningococcal infections, whereas single variants are not over-represented in those patients. In studies on gastrointestinal malignancies, it has been concluded that carrying multiple pro-inflammatory polymorphisms is associated with an increased risk of gastric cancer [4,5]. Furthermore, studies on the relationship between caspase recruitment domain (CARD) 15/nucleotide oligomerisation domain (NOD) 2 genetic variants, of which SNP8, SNP12 and SNP13 are most studied, and Crohn's disease have shown that compound heterozygous subjects (carriers of two different genetic variants, e.g. SNP12 genotype 1.2 and SNP13 genotype 1.2) have a higher risk of Crohn's disease as compared to homozygous subjects (carriers of the same genetic variant on both chromosomes, e.g. SNP12 genotype 2.2) $[6,7]$.

Analogous to these findings, we hypothesized that carrying multiple genetic variations in multiple PRRs (in a socalled carrier trait) may increase the risk of C. trachomatisassociated tubal pathology in subfertile women. According to their biological function (recognition of C. trachomatis PAMPs: see Table 1), four PRRs were selected: TLR9, TLR4, CD14 and CARD15/NOD2. Five relatively common SNPs, which are assumed to influence the receptor function, in these four PRR genes were studied in this carrier trait analysis (see Table 1 ).

\section{Methods \\ Study population}

The study was performed in women who visited the Academic Hospital Maastricht between December 1990 and November 2000 because of subfertility. In all patients blood was drawn at their initial visit for a Chlamydia IgG antibody test (CAT). All spare sera were cryopreserved. Only patients who had undergone a laparoscopy and tubal testing as part of their fertility work-up were included in the present study. Since the prevalence of

Table I: The pattern recognition receptors (PRRs), which recognize C. trachomatis pathogen-associated molecular patterns (PAMPs), and the single nucleotide polymorphisms (SNPs) studied

\begin{tabular}{lll}
\hline PRR & PAMP & SNP \\
\hline TLR9 & CPG-rich motifs & -1237 T>C and $+2848 \mathrm{G}>\mathrm{A}$ \\
TLR4 & LPS and HSP & $+896 \mathrm{~A}>\mathrm{G}$ \\
CDI4 & LPS and HSP (co-receptor of TLR4) & $-260 \mathrm{C}>\mathrm{T}$ \\
CARDI5/NOD2 & Peptidoglycans & Leu I 007fsins (SNPI3) \\
\hline
\end{tabular}

$T L R=$ toll-like receptor; $C D=$ cluster of differentiation; $C A R D=$ caspase recruitment domain; $N O D=$ nucleotide oligomerisation domain; $C P G=$ cytosine-phosphate-guanine; LPS = lipopolysaccharide; HSP = heat shock protein; $T$ = thymine; $\mathrm{C}=$ cytosine; $\mathrm{G}=$ guanine; $\mathrm{A}=\mathrm{adenine} ; \mathrm{Leu}=$ leucine-rich repeat domain; fsins $=$ frameshift insertion . 
SNPs may depend on ethnical background, only Dutch Caucasian women were included. Patients who had undergone previous pelvic surgery (except for an uneventful appendectomy or Caesarean section) were excluded. In the Netherlands, for retrospective analysis of anonymized patient data and stored sera no ethical committee approval is required. In the fertility clinic of the Academic Hospital Maastricht, all couples are informed at intake about possible use of their anonymized data and stored sera for research purposes, and a "no objection procedure" is followed. Only patients having not objected participated in the present study.

Two independent investigators, who were unaware of the CAT results, scored 259 successive laparoscopy reports to assess the grade of tubal pathology. Tubal pathology was defined as extensive peri-adnexal adhesions and/or distal occlusion of at least one tube [8]. In case of disagreement, consensus was reached by consultation.

Of the 259 women who underwent a laparoscopy, 43 $(17 \%)$ had tubal pathology (according to the above-mentioned definition) and 184 (71\%) had no tubal pathology (no peri-adnexal adhesions and patent tubes), and these 227 women participated in the present study. Thirty-two women $(12 \%)$ had minor or non-C. trachomatis-related abnormalities (any peri-adnexal adhesions and/or proximal occlusion of at least one tube) and were excluded.

\section{C. trachomatis IgG antibody testing}

IgG antibodies to C. trachomatis were detected using the species-specific Chlamydia pneumoniae IgG micro-immunofluorescence (MIF) test (AniLabsystems, Finland), as described previously [9]. This species-specific test is able to detect IgG antibodies to both C. pneumoniae and C. trachomatis (using an antigen derived from a C. trachomatis LGV strain, serovar L2). We have previously studied the test performances of five commercially available C. trachomatis IgG tests, including the C. trachomatis IgG spot in the C. pneumoniae MIF (AniLabsystems) [10]. In our hands, the C. trachomatis IgG titre obtained by the C. pneumoniae MIF (AniLabsystems) had the best predictive value for tubal factor subfertility [10]. Therefore, we have used this test in the present study. The cut-off titre used for a positive test was 32.

\section{Immunogenetic analysis}

For the immunogenetic analyses, genomic DNA was extracted from the cryopreserved serum samples using either the MagNaPure LC isolator according to the manufacturers' instructions (Roche Molecular Biochemicals, Germany) or the High Pure PCR Template Preparation (HPPTP) Kit according to the manufacturers' instructions (Roche Molecular Biochemicals, Germany). Both techniques provide enough DNA for reproducible genetic analyses. Genotyping was performed using a polymerase chain reaction (PCR)-based restriction fragment length polymorphism (RFLP)-assay or TaqMan-assay as described previously $[2,11-13]$. The SNPs studied are summarized in Table 1. Chromosomal locations and further information on the genes studied are: TLR9 chromosomal location 3p21.3, TLR9 -1237 T>C rs5743836 and TLR9 +2848 G>A rs352140; TLR4 chromosomal location 9q32q33, TLR4 +896 A>G rs4986790; CD14 chromosomal location 5q31.1, CD14 -260 C>T rs25691909; CARD15/ NOD2 chromosomal location 16q21, CARD15/NOD2 Leu1007fsinsC (SNP13) rs2066847. For ethnicallymatched background genotyping, genomic DNA was extracted from whole blood of 97 healthy Dutch Caucasian employees of the VU University Medical Center. They gave written informed consent for use of their anonymized sera to serve as control sera for genetic research purposes.

\section{Statistical methods}

The genotype distribution was tested for Hardy-Weinberg equilibrium to assess Mendelian inheritance. Fisher's exact or $\chi^{2}$ tests were used to compare the single genotypes between $C$. trachomatis IgG-positive and IgG-negative subfertile women with and without tubal pathology and the healthy control group. Subsequently, the single genotypes were used to define carrier traits. The carrier traits were tested in $\chi^{2}$ and trend analyses. $P<0.05$ was considered statistically significant.

\section{Results}

Of all 227 subfertile women participating in the present study, 43 (19\%) had tubal pathology, whereas $184(81 \%)$ did not have tubal pathology. C. trachomatis IgG antibodies were present in 39 women, of whom $26(67 \%)$ had tubal pathology and 13 (33\%) did not have tubal pathology. C. trachomatis IgG antibodies were absent in 188 women, of whom 17 (9\%) had tubal pathology and 171 (91\%) did not have tubal pathology.

For all genes studied, the genotype distribution was in Hardy-Weinberg equilibrium in the subfertile women and the ethnically-matched control group.

The genotype distribution did not differ between subfertile women, the C. trachomatis IgG-positive subgroup of subfertile women and the healthy control group (Table 2 ), indicating that the subfertile women participating in the study reflect an average Dutch Caucasian population regarding the genotype distribution.

\section{Single gene analysis}

The risk of tubal pathology was assessed in all subfertile women and in the C. trachomatis IgG-positive subgroup in relation to the genotype of TLR9, TLR4, CD14 and 
Table 2: The risk of tubal pathology (TP) in relation to the genotype of the single genes studied.

\begin{tabular}{|c|c|c|c|c|c|}
\hline & & \multicolumn{2}{|c|}{ I.I } & \multicolumn{2}{|c|}{1.2 and 2.2} \\
\hline & & $\mathrm{n}$ & Risk of TP & $\mathrm{n}$ & Risk of TP \\
\hline \multirow[t]{3}{*}{ TLR9 - $1237 \mathrm{~T}>\mathrm{C}$} & All subfertile women & 155 (68\%) & $20 \%$ & $72(32 \%)$ & $17 \%$ \\
\hline & CT+ subfertile women & $26(67 \%)$ & $62 \%$ & $13(33 \%)$ & $77 \%$ \\
\hline & Control group & $66(68 \%)$ & - & $31(32 \%)$ & - \\
\hline \multirow[t]{3}{*}{ TLR9 +2848 G>A } & All subfertile women & $45(20 \%)$ & $18 \%$ & $182(80 \%)$ & $19 \%$ \\
\hline & $\mathrm{CT}+$ subfertile women & $6(15 \%)$ & $50 \%$ & $33(85 \%)$ & $70 \%$ \\
\hline & Control group & $15(15 \%)$ & - & $82(85 \%)$ & - \\
\hline \multirow[t]{3}{*}{ TLR4 +896 A> $\mathrm{G}^{\mathrm{a}}$} & All subfertile women & $200(88 \%)$ & $19 \%$ & $27(12 \%)$ & $22 \%$ \\
\hline & CT+ subfertile women & $33(85 \%)$ & $64 \%$ & $6(15 \%)$ & $83 \%$ \\
\hline & Control group & $87(90 \%)$ & - & $10(10 \%)$ & - \\
\hline \multirow[t]{3}{*}{ CDI4 -260 C>Tb } & All subfertile women & $60(26 \%)$ & $17 \%$ & 167 (74\%) & $20 \%$ \\
\hline & CT+ subfertile women & $12(31 \%)$ & $67 \%$ & 27 (69\%) & $67 \%$ \\
\hline & Control group & $26(27 \%)$ & - & 71 (73\%) & - \\
\hline CARDI5/NOD2 & All subfertile women & $211(93 \%)$ & $18 \%$ & $16(7 \%)$ & $25 \%$ \\
\hline Leul007fsins $C$ & CT+ subfertile women & $37(95 \%)$ & $65 \%$ & $2(5 \%)$ & $100 \%$ \\
\hline (SNPI3) & Control group & $95(98 \%)$ & - & $2(2 \%)$ & - \\
\hline
\end{tabular}

All subfertile women: $n=227$, of whom $19 \%$ has tubal pathology (TP).

$\mathrm{CT}+($ C. trachomatis IgG-positive) subfertile women: $\mathrm{n}=39$, of whom $67 \%$ has TP.

Control group: $n=97$ ethnically-matched healthy employees of the VU University Medical Center.

$\mathrm{I} . \mathrm{I}=$ normal genotype (homozygous for the common allele); I.2 = heterozygous SNP carrier (one common allele and one rare allele); 2.2 =

homozygous SNP carrier (homozygous for the rare allele).

a Adapted from Morré et al., 2003 [I].

b Adapted from Ouburg et al., 2005 [2].

CARD15/NOD2 (Table 2; Figure 1). An increasing risk of tubal pathology was observed across the genotypes in all genes except CD14. Carrying SNPs in these genes increased the risk of tubal pathology (on average almost $20 \%$ ). These differences did not reach statistical significance. These single genotypes were used to define carrier traits.

\section{Carrier trait analysis}

The SNPs in the single genes were combined in carrier traits. The risk of tubal pathology was assessed in C. trachomatis IgG-positive and IgG-negative subfertile women in relation to the number of SNPs. Carrying two or more SNPs did not influence the risk of tubal pathology in $C$. trachomatis IgG-negative women as compared to C. trachomatis IgG-negative women carrying less than two SNPs ( $9 \%$ vs. $8 \%$ risk respectively; Figure 2). However, carrying multiple SNPs doubled the risk of tubal pathology in $C$. trachomatis IgG-positive women as compared to C. trachomatis IgG-positive women with less than two SNPs (73\% vs. 33\% risk respectively; Figure 2). These differences did not reach statistical significance $(P=0.15)$ but a clear trend was observed.

\section{Discussion}

Over the last decade, immunogenetic studies have provided insight in the pathogenesis of and susceptibility to infectious diseases. So far, the role of SNPs in immunolog- ically relevant genes has been established in numerous diseases, e.g. sexually transmitted infections [14-16] and inflammatory bowel diseases (Crohn's disease and ulcerative colitis) $[17,18]$. In this study, we analyzed the role of single SNPs and multiple SNPs in multiple genes (in a socalled carrier trait) as risk factors of $C$. trachomatis-related tubal pathology and we confirmed our hypothesis that a carrier trait based on genes in bacterial sensing pathways had a stronger association with the risk of tubal pathology than a single gene analysis.

Recent studies have shown the value of genetic traits in complex diseases. Carrying multiple SNPs in the same gene, or multiple SNPs in multiple genes, has been associated with an increased risk of infectious diseases and malignancies $[3,4,6,7]$. Analogous to these findings, we hypothesized that the disregulation of the immune response by the presence of multiple SNPs may lead to an even higher risk of tubal pathology following a C. trachomatis infection as compared to carrying a single SNP.

In this study, we investigated the role of five SNPs in four genes which are assumed to play a role in the recognition of $C$. trachomatis (see Table 1). An adequate recognition of C. trachomatis by PRRs is the first step in the immune response. Recent studies have shown that TLR1-9 are expressed in the human female genital tract. TLR4 and its co-receptor CD14 are predominantly expressed in the fal- 


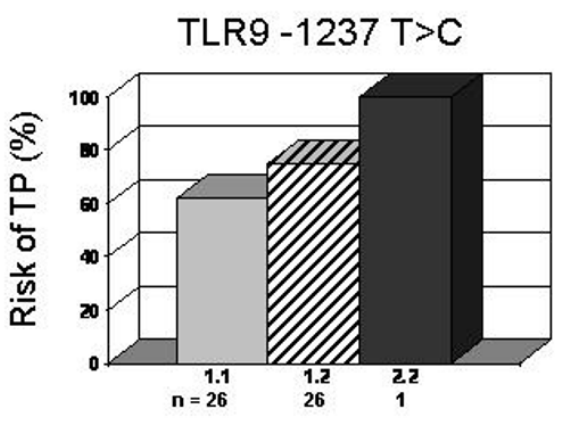

CD14 -260 C> $\mathrm{T}^{\mathrm{b}}$

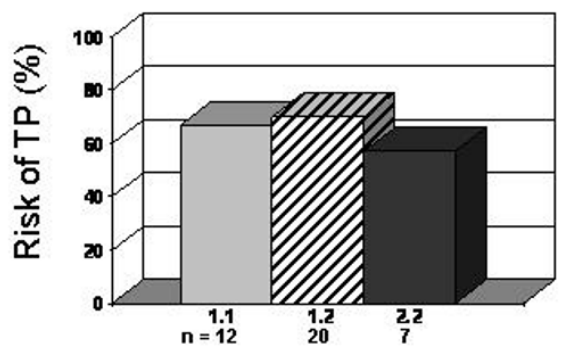

TLR9 +2848 G>A

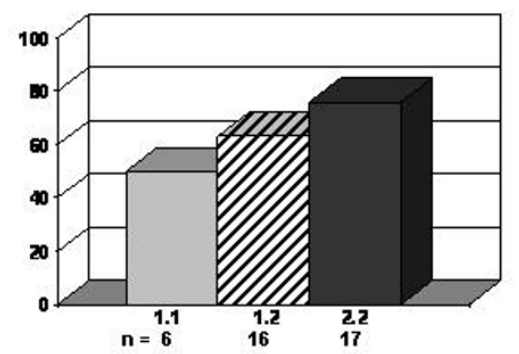

CARD15 / NOD2 SNP13

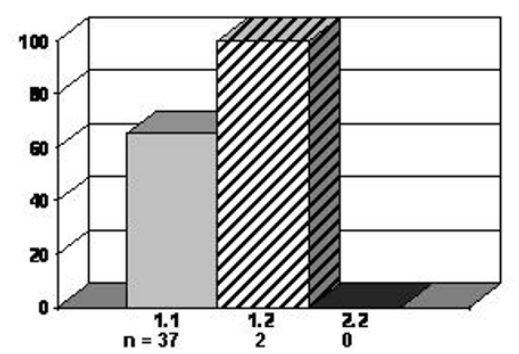

TLR4+896 $A>G^{a}$

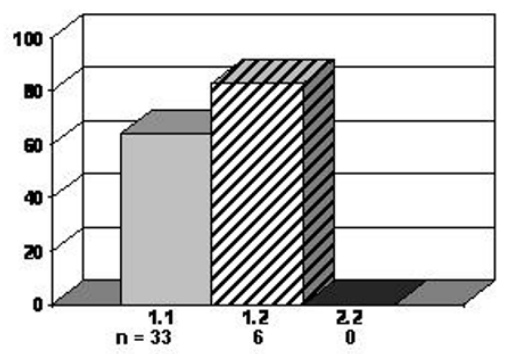

\section{1 (Wildtype)}

WIIA 1.2 (Heterozygote)

2.2 (Mutant)

Figure I

The risk of tubal pathology (TP) in C. trachomatis IgG-positive subfertile women in relation to the genotype of the single pattern recognition receptor genes. a Adapted from Morré et al., 2003 [I]. b Adapted from Ouburg et al., 2005 [2].

lopian tubes, where they may play an important role in the innate host defence mechanism against ascending $C$. trachomatis infections [19-21]. Regarding CARD15/ NOD2, it is not clear whether it plays a role in the C. trachomatis recognition in the genital tract, although NOD proteins have been shown to be involved in the intracellular sensing of C. pneumoniae in endothelial cells [22].

Our data show a doubling of the risk of tubal pathology in C. trachomatis IgG-positive women carrying two or more SNPs as compared to C. trachomatis IgG-positive women carrying less than two SNPs (73\% vs. 33\% risk). The differences did not reach statistical significance $(P=$ 0.15 ) due to the small sample size (227 subfertile women in total, including 39 C. trachomatis IgG-positive subfertile women, of whom $67 \%$ has tubal pathology). If the association found in this pilot study would be confirmed in a larger cohort, a 50\% increase in sample size (to 341 subfertile women) would result in a significant difference $(P$ $=0.047$ ) between $C$. trachomatis IgG-positive subfertile
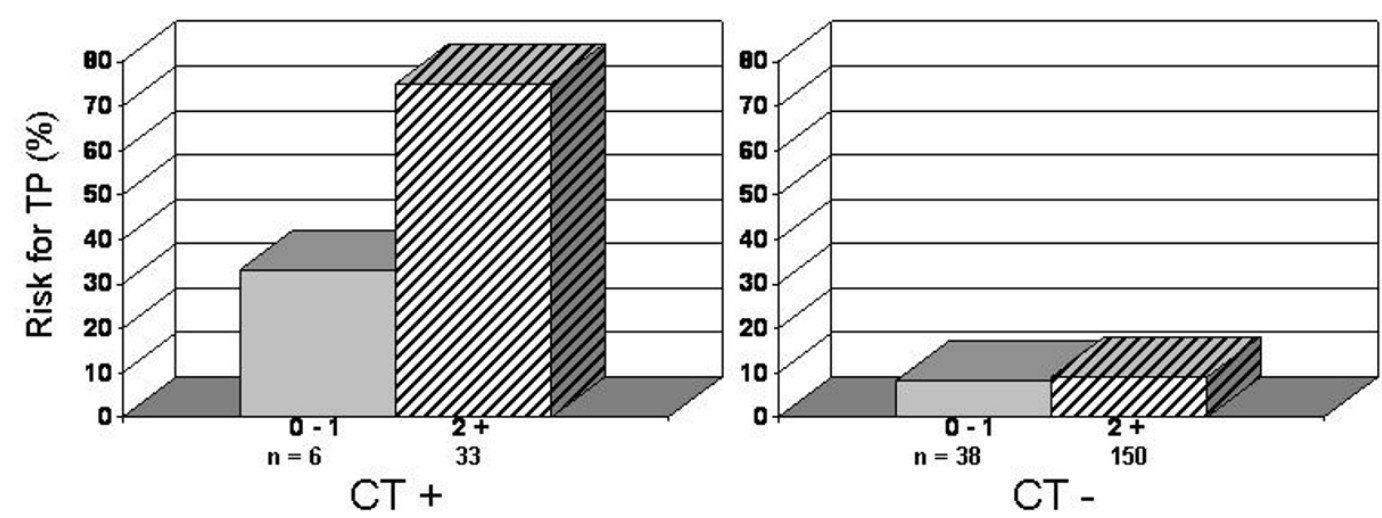

0-1 mutations VIIA 2+ mutations

Figure 2

The risk of tubal pathology (TP) in C. trachomatis IgG-positive (CT+) and IgG-negative (CT-) subfertile women in relation to carrying five single nucleotide polymorphisms (SNPs) in four pattern recognition receptor genes. 
women carrying two or more SNPs versus C. trachomatis IgG-positive subfertile women carrying less than two SNPs regarding the risk of tubal pathology. A $100 \%$ increase in sample size (to 454 subfertile women) would result in a strong association $(P=0.016$; OR: 5.3$)$ between carrying two or more SNPs and an increased risk of tubal pathology. Increasing the sample size twofold would not be possible however in our setting in a reasonable time frame. Although the present study was performed in a large fertility clinic and patients were included during a ten-year period, the number of affected women remained small, due to the low prevalence of IgG-positivity in combination with both carrying multiple SNPs and tubal pathology.

From our results it can be concluded that an adequate recognition of the pathogen at the site of infection seems to be a relevant step in the immune response, and that carrying multiple SNPs in multiple C. trachomatis PRR genes tends to increase the risk of an aberrant immune response and tubal pathology. To draw significant conclusions, our hypothesis should be retested in further studies using a larger cohort.

As expected, a difference in risk of tubal pathology between C. trachomatis IgG-positive women and C. trachomatis IgG-negative women was observed. In previous studies, the presence of C. trachomatis IgG antibodies, an indicator of a previous C. trachomatis infection, has been associated with tubal pathology [23]. Our data show that carrying multiple SNPs in bacterial sensing pathways and a previous $C$. trachomatis infection synergistically enhance the risk of tubal pathology, while carrying these SNPs does not influence the risk of tubal pathology in the absence of a previous C. trachomatis infection (Figure 2).

\section{Conclusion}

We hypothesized that carrier traits (i.e. carrying multiple SNPs in multiple genes) that likely result in an aberrant immune response are associated with tubal pathology following a $C$. trachomatis infection. In 227 subfertile women, we studied five variations in four genes encoding for pattern recognition receptors, which recognize several pathogen-associated molecular patterns of C. trachomatis. The presence of two or more SNPs tends to correlate with an increased risk of tubal pathology following a C. trachomatis infection as compared to a lower number of SNPs. Further studies in a larger cohort are needed to confirm our preliminary findings. An adequate recognition of $C$. trachomatis by receptors in the genital tract seems to be a relevant step in the immune response, and may play a role in protecting the host against the development of late sequelae following a C. trachomatis infection.

\section{Competing interests}

The author(s) declare that they have no competing interests.

\section{Authors' contributions}

JEdH: Data acquisition, statistical analysis, drafting the manuscript.

SO: Data acquisition, statistical analysis, critically revising for immunogenetic content.

JAL: Sample collection, critically revising for medical content.

JML: Partial gene selection based on knock out work, critically reading the manuscript.

JII: Partial gene selection based on knock out work, critically reading the manuscript.

ASP: Critically revising for immunogenetic content.

SAM: Study design, conception and coordination, statistical analysis, critically revising for immunogenetic content.

\section{All authors contributed to writing of the final manuscript.}

All authors read and approved the final manuscript.

\section{Acknowledgements}

Sander Ouburg is an AstraZeneca Nederland BV fellow.

Servaas A. Morré is supported by the Foundation of Immunogenetics, The Netherlands.

The authors acknowledge Jolein Pleijster, from the Laboratory of Immunogenetics of the VU University Medical Center, for excellent technical assistance, and Gert Grauls, from the Department of Medical Microbiology of the Academic Hospital Maastricht, for laboratory assistance.

The ICTI consortium (Integrated approach to the study of Chlamydia trachomatis Infections) provides a broad specialized network for the multidisciplinary studies described [24]. The EpiGenChlamydia consortium http:// www. EpiGenChlamydia.eu is a European Framework Programme 6 (FP6) financially supported Co-ordination Action (CA) in functional genomics research, entitled: Contribution of molecular epidemiology and host-pathogen genomics to understand Chlamydia trachomatis disease.

Part of the data on the single gene analysis has previously been published by our research group $[1,2]$. For the purpose of the present study, these data have been completed, adapted to the current format and (with accurate references) used in the Results section as a basis for the carrier trait anal$y$ sis. Part of the data has been presented as poster presentations at the $16^{\text {th }}$ Biennial Meeting of the International Society for Sexually Transmitted Diseases Research (Amsterdam, The Netherlands, 10-13 July 2005), the IIth Symposium on Human Chlamydial Infections (Niagara-on-the-Lake, Canada, 18-23 June 2006) and the $22^{\text {nd }}$ Annual Meeting of the European Society of Human Reproduction and Embryology (Prague, Czech Republic, I8-21 June 2006). 


\section{References}

I. Morré SA, Murillo LS, Bruggeman CA, Peña AS: The role that the functional Asp299Gly polymorphism in the toll-like receptor-4 gene plays in the susceptibility to Chlamydia trachomatis-associated tubal infertility. I Infect Dis 2003, 187:34|-342.

2. Ouburg S, Spaargaren J, Den Hartog JE, Land JA, Fennema JSA, Pleijster J, Peña AS, Morré SA: The CDI4 functional gene polymorphism -260 C>T is not involved in either the susceptibility to Chlamydia trachomatis infection or the development of tubal pathology. BMC Infect Dis 2005, 5:। |4.

3. Smirnova I, Mann N, Dols A, Derkx HH, Hibberd ML, Levin M, Beutler B: Assay of locus-specific genetic load implicates rare Tolllike receptor 4 mutations in meningococcal susceptibility. Proc Natl Acad Sci USA 2003, I 00:6075-6080.

4. El-Omar EM, Rabkin CS, Gammon MD, Vaughan TL, Risch HA, Schoenberg JB, Stanford JL, Mayne ST, Goedert J, Blot WJ, et al.: Increased risk of noncardia gastric cancer associated with proinflammatory cytokine gene polymorphisms. Gastroenterology 2003, I 24: I 193-1201.

5. Machado JC, Figueiredo C, Canedo P, Pharoah P, Carvalho R, Nabais S, Castro Alves C, Campos ML, Van Doorn LJ, Caldos C, et al.: A proinflammatory genetic profile increases the risk for chronic atrophic gastritis and gastric carcinoma. Gastroenterology 2003, I 25:364-37I.

6. Hugot JP, Chamaillard M, Zouali H, Lesage S, Cézard JP, Belaiche J, Almer S, Tysk C, O'Morain CA, Gassull M, et al.: Association of NOD2 leucine-rich repeat variants with susceptibility to Crohn's disease. Nature 200I, 4I I:599-603.

7. Heresbach D, Gicquel-Douabin V, Birebent B, D'Halluin PN, Heresbach-Le Berre N, Dreano S, Siproudhis L, Dabadie A, Gosselin M, Mosser J, et al.: NOD2/CARDI5 gene polymorphisms in Crohn's disease: a genotype-phenotype analysis. Eur J Gastroenterol Hepatol 2004, 16:55-62.

8. Land JA, Evers JLH, Goossens VJ: How to use Chlamydia antibody testing in subfertility patients. Hum Reprod 1998, 13:1094-1098.

9. Den Hartog JE, Land JA, Stassen FRM, Slobbe-Van Drunen MEP, Kessels $\mathrm{AGH}$, Bruggeman $\mathrm{CA}$ : The role of chlamydia genus-specific and species-specific IgG-antibody testing in predicting tubal disease in subfertile women. Hum Reprod 2004, I 9: I 380-I 384.

10. Land JA, Gijsen AP, Kessels AGH, Slobbe MEP, Bruggeman CA: Performance of five serological chlamydia antibody tests in subfertile women. Hum Reprod 2003, 1 8:2621-2627.

II. Morré SA, Murillo LS, Spaargaren J, Fennema JSA, Peña AS: Role of the toll-like receptor 4 Asp299Gly polymorphism in susceptibility to Candida albicans infection. J Infect Dis 2002, 186: 1377-1379.

12. Murillo LS, Crusius JBA, Van Bodegraven AA, Alizadeh BZ, Peña AS: CARDI 5 gene and the classification of Crohn's disease. Immunogenetics 2002, 54:59-6I.

13. Lammers KM, Ouburg S, Morré SA, Crusius JBA, Gionchetti P, Rizzello F, Morselli C, Caramelli E, Conte R, Poggioli G, et al:: Combined carriership of TLR9 -I237C and CDI4 -260T alleles enhances the risk of developing chronic relapsing pouchitis. World J Gastroenterol 2005, I I:7323-7329.

14. Jeremias J, Giraldo P, Durrant S, Ribeiro-Filho A, Witkin SS: Relationship between Ureaplasma urealyticum vaginal colonization and polymorphism in the interleukin-I receptor antagonist gene. J Infect Dis 1999, I80:912-914.

15. Kinnunen AH, Surcel HM, Lehtinen M, Karhukorpi J, Tiitinen A, Halttunen M, Bloigu A, Morrison RP, Karttunen R, Paavonen J: HLA DQ alleles and interleukin-IO polymorphism associated with Chlamydia trachomatis-related tubal factor infertility: a casecontrol study. Hum Reprod 2002, I 7:2073-2078.

16. Wang C, Tang J, Geisler WM, Crowley-Nowick PA, Wilson CM, Kaslow RA: Human leukocyte antigen and cytokine gene variants as predictors of recurrent Chlamydia trachomatis infection in high-risk adolescents. J Infect Dis 2005, I 9 I: I 084-1092.

17. Franchimont D, Vermeire S, El Housni H, Pierik M, Van Steen K, Gustot T, Quertinmont E, Abramowicz M, Van Gossum A, Devière J, et al.: Deficient host-bacteria interactions in inflammatory bowel disease? The toll-like receptor (TLR)-4 Asp299gly polymorphism is associated with Crohn's disease and ulcerative colitis. Gut 2004, 53:987-992.

18. Peeters H, Vander Cruyssen B, Laukens D, Coucke P, Marichal D, Van Den Berghe M, Cuvelier C, Remaut E, Mielants H, De Keyser F, et al.:
Radiological sacroiliitis, a hallmark of spondylitis, is linked with CARD I 5 gene polymorphisms in patients with Crohn's disease. Ann Rheum Dis 2004, 63:1 I31-1 I34.

19. Pioli PA, Amiel E, Schaefer TM, Connolly JE, Wira CR, Guyre PM: Differential expression of Toll-like receptors $\mathbf{2}$ and $\mathbf{4}$ in tissues of the human female reproductive tract. Infect Immun 2004, 72:5799-5806.

20. Schaefer TM, Desouza K, Fahey JV, Beagley KW, Wira CR: Toll-like receptor (TLR) expression and TLR-mediated cytokine/ chemokine production by human uterine epithelial cells. Immunology 2004, I I 2:428-436.

21. Fazeli A, Bruce C, Anumba DO: Characterization of Toll-like receptors in the female reproductive tract in humans. Hum Reprod 2005, 20:1372-1378.

22. Opitz B, Förster S, Hocke AC, Maass M, Schmeck B, Hippenstiel S, Suttorp N, Krüll M: Nod I-mediated endothelial cell activation by Chlamydophila pneumoniae. Circ Res 2005, 96:319-326.

23. Punnonen R, Terho P, Nikkanen V, Meurman O: Chlamydial serology in infertile women by immunofluorescence. Fertil Steril 1979, 3 1:656-659.

24. Morré SA, Spaargaren J, Ossewaarde JM, Land JA, Bax CJ, Dörr PJ, Oostvogel PM, Vanrompay D, Savelkoul PHM, Pannekoek Y, et al.: Description of the ICTI consortium: an integrated approach to the study of Chlamydia trachomatis infection. Drugs Today 2006, 42(Suppl A): I07-I I4.

\section{Pre-publication history}

The pre-publication history for this paper can be accessed here:

http://www.biomedcentral.com/1471-2334/6/122/pre pub
Publish with Bio Med Central and every scientist can read your work free of charge

"BioMed Central will be the most significant development for disseminating the results of biomedical research in our lifetime. "

Sir Paul Nurse, Cancer Research UK

Your research papers will be:

- available free of charge to the entire biomedical community

- peer reviewed and published immediately upon acceptance

- cited in PubMed and archived on PubMed Central

- yours - you keep the copyright

Submit your manuscript here:

http://www.biomedcentral.com/info/publishing_adv.asp
BioMedcentral 